\title{
Big bangs in perception: The most often cited authors and publications
}

\author{
MURRAY J. WHITE \\ Victoria University of Wellington, Wellington, New Zealand
}

\begin{abstract}
Textbook citations identified historically important writers and publications in the psychology of perception. The influence of these writers and publications on present research was gauged from citations appearing in the current journal literature.
\end{abstract}

A publication that has never been referred to, during a life of 5 or 10 or 50 years, can reasonably be assumed to have had no impact on science and scholarship. A publication that has been regularly and frequently cited can be assumed to have had an influence, at least on the scholars and scientists doing the citing. The notion that citations tell us something about the scholarly impact of publications and their authors has more than intuitive appeal; there is, in fact, a relation between citations, criteria for influence such as awards and honors, and subjective ranking (Cole \& Cole, 1972; Myers, 1970). Thus, although the average for all authors is under 10 citations a year, certain authors, such as Nobel laureates and Fellows of learned societies, have yearly averages running into the hundreds. Also, although the average citation rate for all publications is under 2 a year (75\% of all publications never being cited), there are some works that are cited hundreds of times a year (Garfield, 1979).

Journals and textbooks provide the two main sources of citation data. Citations in the current journal literature, such as those recorded in the Science Citation Index and the Social Science Citation Index, are useful for determining the impact a publication is having on current research; however, for establishing the formative influence and enduring value of a publication-its historical value-these data are not as meaningful as are citations appearing in scholarly textbooks. An example will clarify this point. In 1924, the American Journal of Psychology published an article by Jenkins and Dallenbach called "Obliviscence During Sleep and Waking." This paper stimulated a good deal of research and theoretical debate and, in the ensuing 30 to 40 years, was widely cited. By the 1970s, however, it was cited in scientific journals on average less than three times a year, although, and importantly, it was continually being referred to in relevant textbooks. In short, although this paper is no longer having much of an influence on research, there is a consensus among experts-the writers of textbooksthat it occupies an immutable position in the history of memory research.

The author's mailing address is: Psychology Department, Victoria University of Wellington, Private Bag, Wellington, New Zealand.
In the present exercise, I have used the citations in 11 undergraduate texts to identify writers and publications of historical importance in the psychology of perception. Citations in the current journal literature indicate what effect these writers and works are having on present research.

\section{METHOD}

Citations were taken from the following books (full details about these books are given in the References section below): Coren, Porac, and Ward (1984); Dember and Warm (1979); Haber and Hershenson (1980); Hochberg (1978); Kaufman (1974); Levine and Shefner (1981); Matlin (1983); McBurney and Collings (1984); Rock (1975); Schiffman (1982); and Sekuler and Blake (1985). The most cited authors and publications found here were checked in the 1983, 1984, and 1985 Social Science Citation Index and Science Citation Index.

\section{RESULTS AND DISCUSSION}

\section{The Publications}

Table 1 summarizes the principal citation statistics for publications. Just under 6,200 works were cited in the 11 texts; 3 works were referred to in all 11 books, and over 5,000 were cited once-in only 1 book. (Before continuing, the reader may care to have a stab at the identities of the 3 scoring publications.) It is clear that an author did well to have a publication cited in even 2 texts, for although 1,075 publications were cited in 2 or more books, they amounted to only $17 \%$ of the total number. A more outstanding achievement would have been to have a work cited in 8 or more of the textbooks; only one half of $1 \%$ of all publications were so cited. This frequency was used, arbitrarily to be sure, to develop a manageable list of outstanding publications (see Appendix A).

A number of observations are in order here. First, the publications in Appendix A covered a period of nearly 100 years. The earliest work, Helmholtz's Treatise, was published in 1867, and the most recent, Gilchrist's paper, in 1977. (Readers should remember that the oldest textbook from which the citations were taken was dated 1974.) Second, there was much variability in the frequency with which the 32 works were cited in recent journals. The very high rates, for the publication by Green and Swets 
Table 1

Distribution of Citations

\begin{tabular}{ccrr}
\hline $\begin{array}{c}\text { Number of Texts } \\
\text { in Which Work } \\
\text { Was Cited }\end{array}$ & $\begin{array}{c}\text { Number of } \\
\text { Cited Works }\end{array}$ & Percent & $\begin{array}{c}\text { Cumulative } \\
\text { Percent }\end{array}$ \\
\hline 11 & 3 & 0.05 & 0.05 \\
10 & 3 & 0.05 & 0.10 \\
9 & 6 & 0.10 & 0.20 \\
8 & 20 & 0.32 & 0.52 \\
7 & 20 & 0.32 & 0.84 \\
6 & 43 & 0.69 & 1.53 \\
5 & 66 & 1.07 & 2.60 \\
4 & 117 & 1.89 & 4.49 \\
3 & 244 & 3.94 & 8.43 \\
2 & 553 & 8.93 & 17.36 \\
1 & 5119 & 82.64 & 100.00 \\
& 6194 & 100.00 & \\
\hline
\end{tabular}

and that by Hubel and Wiesel, are because these works have implications for a range of research areas outside mainstream psychology. The lowish rates, for the publications by Holway and Boring, Wallach, and a few others, confirms the point that textbooks are the preferred indicators of a publication's historical worth. For example, the 1941 paper by Holway and Boring is not currently having much impact on research, and it would not have been featured in Appendix A had current citations been used as the criterion of historical influence.

Third, and with respect to the nature of the publications, there was a reasonable balance in numbers between those that had made original theoretical and empirical contributions (the likes of the paper by Attneave and that by Hecht, Shlaer, \& Pirenne) and those that had made wideranging surveys of a topic or an area (e.g., the publications by Hochberg and by Kaufman). Although the range of topics was wide, visual subject matter was preponderant. As might have been expected, all 11 texts dealt with vision, but only 7 dealt as well with hearing and only 5 with taste, smell, and touch. (This proportional treatment is not peculiar to the present sample of books.) Readers interested in these last-named areas will want to know which publications were most frequently cited, and for this information they are referred to Appendix B. Each of these particular works was cited in at least 4 of the textbooks.

Fourth and finally, it can be noted that 19 of the 44 works (43\%) identified in Appendices A and B were books or chapters in books. This percentage is close to that found for highly cited publications in memory and cognition, substantiating the view that psychologists see books and journals as equally important sources of archival material; in the natural and physical sciences, the most often cited publications are journal papers (White, 1983). To get a more representative picture of publication outlets, I looked at the 278 publications that had been cited in four or more of the texts. Interestingly, six journals accounted for 126 (45\%) of these publications (and for $64 \%$ of all journal articles). Science accounted for 36 (13\%), American Journal of Psychology for 23 (8\%), Scientific American for
20 (7\%), Psychological Review for 17 (6\%), Journal of Experimental Psychology for 16 (6\%), and Perception \& Psychophysics for 14 (5\%). A similar phenomenon is found with journal citations: In the whole field of scientific publications, a relatively small core of around 150 journals accounts for about half the number of all citations (Garfield, 1972).

\section{The People}

The perceptive reader will have been struck by the absence from Appendices A and B of many famous and "obvious" names in perception. Quite clearly, there are people who have made weighty contributions and who have failed to write a best citer.

As an indicator of personal eminence, I decided to use extent of citation rather than sheer productivity or number of cited publications. If a person had been cited by name in at least eight of the texts, and also if the person's senior- and junior-author publications had been discussed and referred to in at least 50 of the books' textual pages (of which there were 4,700), then he or she was marked out as an eminent scholar. The results of applying these criteria are shown in Table 2.

Table 2 also shows the yearly average number of times each person's works were cited in the journal literature in the period 1983-1985. (The constraints of the data sources limited these rates to senior-author publications alone.) As a basis for comparison, it can be noted that of the 100 most frequently cited psychologists, in all fields, for 1975, the 100th-ranked person had 134 citations (Endler, Rushton, \& Roediger, 1978).

One curious finding was the idiosyncratic way in which authors cited a person's publications. The point can be illustrated using the pre-1973 publications of Leibowitz

Table 2

The Most Cited Authors

\begin{tabular}{lr}
\hline \multicolumn{1}{c}{ Author } & Citations in Journals* \\
\hline G. von Békésy & 64 \\
C. Blakemore & 143 \\
E. G. Boring & 84 \\
S. Coren & 88 \\
T. N. Cornsweet & 49 \\
E. J. Gibson & 134 \\
J. J. Gibson & 249 \\
R. L. Gregory & 99 \\
C. S. Harris & 25 \\
R. Held & 45 \\
H. von Helmholtz & 67 \\
J. E. Hochberg & 84 \\
D. H. Hubel & 532 \\
B. Julesz & 161 \\
L. Kaufman & 39 \\
H. W. Leibowitz & 46 \\
U. Neisser & 261 \\
L. A. Riggs & 23 \\
I. Rock & 89 \\
S. S. Stevens & 250 \\
H. Wallach & 61 \\
T. N. Wiesel & 101 \\
\hline
\end{tabular}

*Yearly average, 1983-1985, for senior-author publications. 
(pre-1973 because the earliest text was dated 1974). Leibowitz had 29 such senior- and junior-author works cited throughout the 11 texts, 11 of which were cited once (in only 1 book), 9 twice, 3 three times, 4 four times, 1 five times, and 1 that was cited in 6 textbooks. However, no 2 texts had identical bibliographies of Leibowitz's publications, and in only one instance were the same 2 of his publications cited in 2 texts.

This characteristic was quite general for the more productive researcher. Text 1 would cite publications A, D, L, and N; Text 2, publications B, P, Q, and X; Text 3, publications $\mathrm{A}, \mathrm{F}$, and $\mathrm{G}$; and so on. It accounts for why there were so few commonly cited publications (Table 1); however, why the writers of textbooks should cite works that have been infrequently cited in other books-if in fact they do this knowingly-is less obvious. There may be sound marketing reasons for not referring to works that have already been cited to death; a book could be plugged on the basis of its unique and innovative treatment of the literature. Of course, from the points of view of scholarship and science, such behavior would be difficult to defend and, one imagines, even harder to practice.

\section{CONCLUSIONS}

This article has put on record the names of authors and publications which, in the opinion of 18 informed people, have had a significant impact in the history of the psychology of perception. Apart from their archival value, the findings have identified core works in a broad range of research areas; they usefully serve as a basic reading guide. They also may serve a less scholarly purposethat of testing the acumen of one's colleagues. (The three scoring publications, previously referred to, were the 8th, 9th, and 15th, in Appendix A.)

\section{REFERENCES}

Cole, J. R., \& Cole, S. (1972). The Ortega hypothesis. Science, 178, 368-375.

Coren, S., Porac, C., \& Ward, L. M. (1984). Sensation and perception (2nd ed.). New York: Academic Press.

DEMBER, W. N., \& WARM, J. S. (1979). Psychology of perception (2nd ed.). New York: Holt, Rinehart \& Winston.

Endler, N. S., Rushton, J. P., \& Roediger, H. L., JR. (1978). Productivity and scholarly impact (citations) of British, Canadian, and U.S. Departments of Psychology. (1975). American Psychologist, 33, 1064-1082.

GARFIELD, E. (1972). Citation analysis as a tool in journal evaluation. Science, 178, 61-68.

GARFIELD, E. (1979). Citation indexing. New York: Wiley.

HABER, R. N., \& Hershenson, M. (1980). Psychology of visual perception (2nd ed.). New York: Holt, Rinehart \& Winston.

HochberG, J. E. (1978). Perception (2nd ed.). Englewood Cliffs, NJ: Prentice-Hall.

Kaufman, L. (1974). Sight and mind. New York: Oxford University Press.

LeVINE, M. W., \& SHEFner, J. M. (1981). Sensation and perception. Reading, MA: Addison-Wesley.

Matun, M. W. (1983). Perception. Boston: Allyn \& Bacon.
McBurney, D. H., \& Collings, V. B. (1984). Introduction to sensation and perception (2nd ed.). Englewood Cliffs, NJ: Prentice-Hall. MYERS, C. R. (1970). Journal citations and scientific eminence in contemporary psychology. American Psychologist, 25, 1041-1048.

Rock, I. (1975). Introduction to perception. New York: Macmillan. SChiffmaN, H. R. (1982). Sensation and perception (2nd ed.). New York: Wiley.

Science Citation Index. (1983-1985). Philadelphia, PA: Institute for Scientific Information.

Social Science Citation Index. (1983-1985). Philadelphia, PA: Institute for Scientific Information.

Sekuler, R., \& Blake, R. (1985). Perception. New York: Knopf.

White, M. J. (1983). Prominent publications in memory and cognition. Memory \& Cognition, 11, 423-427.

\section{APPENDIX A}

\section{The Most Cited Publications}

ATtNeAve, F. (1954). Some informational aspects of visual perception. Psychological Review, 61, 183-193. [11]

Boring, E. G. (1942). Sensation and perception in the history of experimental psychology. New York: Appleton-Century-Crofts. [18] CherRy, E. C. (1953). Some experiments on the recognition of speech, with one and with two ears. Journal of the Acoustical society of America, 25, 975-979. [5]

Coren, S. (1972). Subjective contours and apparent depth. Psychological Review, 79, 359-367. [10]

CoRnsweEt, T. N. (1970). Visual perception. New York: Academic Press. [19]

FanTZ, R. L. (1961). The origin of form perception. Scientific American, 204, 66-72. [5]

GIBSON, E. J. (1969). Principles of perceptual learning and development. New York: Appleton-Century-Crofts. [41]

GiBson, J. J. (1950). Perception of the visual world. Boston: Houghton Mifflin. [39]

GiBson, J. J. (1966). Senses considered as visual systems. Boston: Houghton Mifflin. [56]

GiLCHRIST, A. L. (1977). Perceived lightness depends on perceived spatial arrangement. Science, 195, 185-187. [4]

GREEN, D. M., \& SWETS, J. A. (1966). Signal detection theory and psychophysics. New York: Wiley. (Reprinted, 1974.) [104]

GREGORY, R. L. (1966). Eye and brain. New York: World University Library. (2nd ed., 1969; 3rd ed., 1977.) [15]

HeBB, D. O. (1949). Organization of behavior. New York: Wiley. [80]

Hecht, S., Shlaer, S., \& Pirenne, M. H. (1942). Energy, quanta, and vision. Journal of General Physiology, 25, 819-840. [3]

HeLmHOLTZ, H. voN (1867). Treatise on physiological optics. Translated from the 3rd German edition, J. P. Southall (Ed.). New York: Dover, 1962. [42]

Hochberg, J. E. (1971). Perception: I. Colour and shape. In J. W. Kling \& L. A. Riggs (Eds.), Woodworth and Schlosberg's experimental psychology (3rd ed., pp. 395-474). New York: Holt, Rinehart \& Winston. [6]

HochBerG, J. E. (1971). Perception: II. Space and movement. In J. W. Kling \& L. A. Riggs (Eds.), Woodworth and Schlosberg's experimental psychology (3rd ed., pp. 475-550). New York: Holt, Rinehart, \& Winston. [6]

Holway, A. F., Boring, E. G. (1941). Determinants of apparent visual size with distance invariant. American Journal of Psychology, 54, 21-37. [2]

Hubel, D. H., \& Wiesel, T. N. (1962). Receptive fields, binocular interaction, and functional architecture in the cat's visual cortex. Journal of Physiology, 160, 106-154. [135]

Hubel, D. H., \& Wiesel, T. N. (1968). Receptive fields and functional architecture of monkey striate cortex. Journal of Physiology, 195, 215-243. [52]

Julesz, B. (1971). Foundations of Cyclopean perception. Chicago: University of Chicago Press. [54] 
Kaufman, L. (1974). Sight and mind. New York: Oxford University Press. [8]

LiNDSAY, P. H., \& NoRMAN, D. A. (1972). Human information processing. New York: Academic Press. (2nd ed., 1977.) [31]

MarKs, W. B., Dobelle, W. H., \& MacNichol, E. F. (1964). Visual pigments of single primate cones. Science, 143, 1181-1183. [6]

RATLIFF, F. (1965). Mach bands: Quantitative studies on neural networks in the retina. San Francisco: Holden-Day. [16]

Riggs, L. A., Ratuiff, F., \& CoRnsweet, T. N. (1953). Disappearance of steadily fixated visual test objects. Journal of the Optical Society of America, 43, 495-501. [10]

RuBIN, E. (1915). Synsoplevede figurer. Copenhagen: Gyldendaske. (Translated into German, 1921; abridged version of translation in English, 1962.) [10]

Sexuler, R. W., \& Ganz, L. (1963). Aftereffect of seen motion with a stabilized retinal image. Science, 139, 419-420. [4]

SPERLING, G. (1960). Information available in brief visual presentations. Psychological Monographs, 74(Whole No. 498). [33]

Wallach, H. (1948). Brightness constancy and the nature of achromatic colors. Journal of Experimental Psychology, 38, 310-324. [2]

WALLACH, H., \& O'CoNNELL, D. N. (1953). Kinetic depth effect. Journal of Experimental Psychology, 45, 205-217. [9]

WERTHEIMER, M. (1923). Untersuchungen zur Lehre von der Gestalt, II. Psychologische Forschung, 4, 301-350. (Abridged translation, in English, 1958.) [15]

Note-The numbers in brackets are the yearly average citation rates in journals for 1983-1985. Citations to editions shown in parentheses have been included in these averages.

\section{APPENDIX B}

The Most Cited Publications in Hearing, Taste, Smell, and Touch and Pain

\section{Hearing}

BÉKÉSY, G. voN (1960). Experiments in hearing. New York: McGrawHill. [38]

GuLICK, W. L. (1971). Hearing: Physiology and psychophysics. New York: Oxford University Press. [2]
STEVENS, S. S. (1956). The direct estimation of sensory magnitudes: Loudness. American Journal of Psychology, 69, 1-25. [8]

\section{Taste}

Collings, V. B. (1974). Human taste response as a function of locus of stimulation on the tongue and soft palate. Perception \& Psychophysics, 16, 169-174. [3]

MCBURNEY, D. H., \& GENT, J. F. (1979). On the nature of taste qualities. Psychological Bulletin, 86, 151-163. [3]

SCHIFFMAN, S. S., \& DACKIS, C. (1975). Taste of nutrients: Amino acids, vitamins, and fatty acids. Perception \& Psychophysics, 17, 140-146. [3]

\section{Smell}

CAIN, W. S. (1977). Differential sensitivity for smell: Noise at the nose. Science, 195, 796-798. [1]

CaIN, W. S. (1979). To know with the nose: Keys to odor identification. Science, 203, 467-470. [3]

Schiffman, S. S. (1974). Physiochemical correlates of olfactory quality. Science, 185, 112-117. [2]

\section{Touch and Pain}

Melzack, R., \& CASEY, K. L. (1968). Sensory, motivational, and central control determinants of pain. In D. R. Kenshalo (Ed.), The skin senses (pp. 423-443). Springfield, IL: Thomas. [11]

Melzack, R., \& Wall, P. D. (1965). Pain mechanisms: A new theory. Science, 150, 971-979. [84]

WeInstein, S. (1968). Intensive and extensive aspects of tactile sensitivity as a function of body part, sex, and laterality. In D. R. Kenshalo (Ed.), The skin senses (pp. 195-218). Springfield, IL: Thomas. [5]

Note-The numbers in brackets are the yearly average citation rates in journals for 1983-1985. Citations to editions shown in parentheses have been included in these averages.

(Manuscript received for publication April 4, 1987.) 